\title{
A Proposed Relationship between Organizational Safety Practices and Safety Performance in the Manufacturing of Small and Medium Enterprises in Malaysia
}

\author{
Mohd Zaidi Mat Saat*, Chandrakantan Subramaniam, Faridahwati Mohd Shamsudin
}

School of Business Management (SBM), Universiti Utara Malaysia, 06010 UUM Sintok, Kedah, Malaysia

*Corresponding author: s95720@student.uum.edu.my

\begin{abstract}
Many studies have showed that 60 percent to 80 percent of all industrial accidents were likely due to human errors. Inability of employees to manage work overload, provide appropriate response, and conduct proper activities are the bases for human erors. Safety performance in SMEs is an issue of concern because of increasing accidents and injury rates. Due to the vulnerability of SMEs to workplace accidents and illnesses researchers have begun to develop a considerable interest in addressing the issue. The aim of this paper is to review related empirical literatures and emphasize the necessity to examine safety performance among manufacturing SMEs in Malaysia. This paper discusses the role of organizational safety practices that may have an influence on safety performance. Toward the end of the paper, a conceptual model illustrating the relationships between organizational safety practices and safety performance will be presented.
\end{abstract}

Keywords: Organizational safety practices, safety performance, manufacturing SMEs

(C) 2016 Penerbit UTM Press. All rights reserved

\subsection{INTRODUCTION}

Malaysia is moving forward to become a developed and high income nation and small and medium enterprises (SMEs) remain a crucial element in the country's economic growth. SMEs are categorized according to either their annual sales turnover or the number of full-time employees and the definition differs somewhat by industry/sector (SME Corporation Malaysia, 2014). There are currently 662,939 companies in operation all over Malaysia and SMEs account for 97.3\% of the entire number of business in the nation (SME Annual Report, 2014/2015). In 2014, SMEs employed about 6.2 million or 65 percent of total employment. In terms of gross domestic product (GDP), SMEs accounted for 35.9 percent of the overall GDP in 2014 (SME Annual Report, 2014/2015). According to the economic census on the profile of small and medium enterprises (Department of Statistics Malaysia, 2011) in 2010, 95.4\% establishments are categorized as SMEs in the manufacturing sector of the total establishments.

Considering their enormous contribution to the country's economic growth, the government's dedication in enhancing the growth of SMEs can be noticed since early 1970s (Saleh \& Ndubisi, 2006) in terms of providing various forms of assistance. These include market access and financial aid, research and development, use of information and communication technology, technological support and quality control and also access to skilled labors (SME Annual Report, 2014/2015). Consequently, the economic contribution of SMEs to the overall GDP constantly increased from 2005 till 20113 (SME Annual Report, 2014/2015). But despite their economic significance, SMEs in Malaysia remain to encounter many challenges. According to several researchers (Leman, Omar, \& Yusuf, 2010; Surienty, Hong, \& Hung, 2011), one of the challenges encountered by the Malaysian SMEs is the high rate of workplace accidents which reflects poorly how safety and employees' welfare are being managed by the companies. To date, there are no official statistics or reports of number of accidents of SMEs; however, statistics of number of accidents by each industry are available from the Social Security Organization (SOCSO). Table 1 exhibits that the manufacturing industry recorded the highest number of accidents from 2010 till 2014 in comparison to other industries.

Table 1 Number of accidents reported by industry (2010-2014)

\begin{tabular}{|l|c|c|c|c|c|}
\hline \multicolumn{1}{|c|}{ Industry } & $\mathbf{2 0 1 0}$ & $\mathbf{2 0 1 1}$ & $\mathbf{2 0 1 2}$ & $\mathbf{2 0 1 3}$ & 2,135 \\
\hline $\begin{array}{l}\text { Agriculture, } \\
\text { forestry } \\
\text { fishing }\end{array}$ & 2,561 & 2,410 & 2,267 & 2,249 & 453 \\
\hline $\begin{array}{l}\text { Mining and } \\
\text { quarrying }\end{array}$ & 370 & 421 & 426 & 411 & 15,323 \\
\hline Manufacturing & 17,569 & 17,106 & 16,684 & 16,145 & 6,552 \\
\hline Construction & 4,665 & 4,937 & 5,177 & 5,908 & \\
\hline
\end{tabular}


According to Datuk Seri Ismail Abd Muttalib, the Human Resources Deputy Minister, the manufacturing, services, and retail and wholesale trading sectors have been identified as major contributors to accidents at the workplace in 2014 ("Three sectors major contributors to accidents at the workplace," 2014). Datuk Dr. Johari Basri (2010), the former Director General of Department of Occupational Safety and Health Malaysia (DOSH), expressed that approximately 80 percent of the total number of industrial accidents occurred in SMEs ("80 peratus kemalangan industry babitkan IKS," 2010). Recently, Ahmad Kahar Abu Bakar, the Director of DOSH Negeri Sembilan stated that the largest contributor to the country's industrial accident is the SMEs, which account for nearly 90 percent of workplace accidents ("JKKP giat kurangkan kemalangan tempat kerja," 2015).

In sum, these statistics show a quite somber picture of the status of industrial accidents in the country, justifying a need to find practical solutions to minimize, if not eliminate them, from the workplace especially in SMEs, which remain the economic backbone for the country. Unless and until industrial accidents could be seriously curbed, the loss to the country will be tremendous and the route to becoming a developed nation by 2020 may be adversely affected.

One of the approaches primarily used to explain workplace accidents and their solutions is management perspective. It asserts that human error is the primary cause of workplace accidents (Bottani, Monica, \& Vignali, 2009; Enshassi, Choudhry, Mayer, \& Shoman, 2008; Fahlbruch, 2009; Gordon, Flin, \& Mearns, 2005; Jiang, Yu, Li, \& Li, 2010; Ryerson \& Whitlock, 2005). Such error can be decreased by providing proper policies and procedures which refer to the formal instructions or guidelines that employees need to perform a task or job, such as operating procedures, checklists, and emergency operating procedures and safety knowledge to employees, which consequently reduce workplace accidents (Gordon et al., 2005). Many studies have showed that 60 percent to 80 percent of all industrial accidents were likely due to human errrors (Fleming \& Lardner, 1999; Hollnagel, 1993; Kuhlmann, 2003; Ryerson \& Whitlock, 2005).

Human factor theory and Petersen's accident/incident theory of accident causation guide the management perspective. Inability of employees to manage work overload, provide appropriate response, and conduct proper activities are the bases for human error, postulated by human factor theory (Goetsch, 2011). Petersen accident theory claims that management failure and personnel failure contribute to workplace accidents (Goetsch, 2011; Salmon \& Lenne, 2009). Several studies (e.g., Enshassi et al., 2008; Fernandez-Muniz, Montes-Peon, \& Vazquez-Ordas, 2009) applied this perspective to explain workplace accidents.

This study strives to assess the impact of organizational safety practices on safety performance. Organizational safety practices are considered because Petersen Organizational safety practices are considered because Petersen accident theory indicates the accountability of management failure in workplace accidents (Goetsch, 2011). The consideration of organizational safety practices in understanding safety performance is vital for two reasons. Firstly, according to Barling (2001), organizational safety practices have the capacity to address threats and circumstances that stimulate the occurrence of human errors by improving safety standards in the organization. Secondly, management lays out the rules, procedures, and information to the employees, resulting in reduced accidents and injuries in the organization (Fernandez-Muniz, Montes-Peon, \& Vazquez-Ordas, 2007; Shang, Yang, \& Lu, 2011; Vinodkumar \& Bhasi, 2010). Organizational safety practices can be seen as actions conducted by the management to promote the standards of safety performance in the organization. Hence, this present study applies the management perspective to explaining safety performance in the manufacturing industry of SMEs in Malaysia.

\subsection{THEORETICAL FOUNDATION OF THE STUDY}

\section{Human Factors Affecting Safety Performance}

Human factors are essential in clarifying human involvement in safety behavior (Fahlbruch \& Wilpert, 1999). Work behavior influencing safety performance encompasses 'environmental, organizational, and job factors and human and individual characteristics' (Gordon \& Risley, 1999). Furthermore, human factors are defined as all things that need to be controlled to obtain reliable human performance (Fahlbruch, 2009).

Human factors also concern employees' level of discipline which denotes to the matching of capabilities, limitations, and needs based with human behavior (Bellamy, Geyer, \& Wilkinson, 2008). Besides, workplace improvement, in regards to occupational safety and worker's health, depends on the organizational factor, individual characteristics and job factors (Fahlbruch, 2009; Tam, Zeng, \& Deng, 2004).

The link between human factor with occupational accidents and safety performance has been addressed in many studies. Wolfram (1993) found that human factors can raise the level of safety performance and also reduce occupational accidents. Wolfram further emphasizes that due to ignorance, weak control, misinterpretation, and fatigue, such accidents are bound to happen. This is supported by UK HSE (2003) that states that 80 percent of accidents may be partly attributed to the actions or negligence of persons or to the effects of human factors in an organization. Research on workplace safety, with regard to human factors by the University of Aberdeen, reveal that several human factors significantly affect safety including the propensity to report occupational accidents and injuries, communication about safety, and satisfaction with safety activities (UK HSE, 2003).

A number of empirical studies (e.g., Booth \& Lee, 1995; Bottani et al., 2009; Hughes \& Kornowa-Weichel, 2004; Ryerson \& Whitlock, 2005; Salmon \& Lenne, 2009) have focused on human errors in studying human factors that affect safety. For instance, Reason (1990) elucidates that human error is "a generic term to encompass that entire situation in which a series of planned expectations of mental or physical activities fails to achieve its intended outcome, and when these failures cannot be attributed to the intervention of some change agency" (Reason, 1990).

Heinrich, Peterson and Roos (1980) note that tracking an accident can be done by examining its causes, for instance human errors. The researchers determine that an accident is a form of human error, which may be conscious or otherwise and may be based on certain types of logic. Wiegmann and Shappell (2001) from the US aviation industry found that $70 \%$ to $80 \%$ of human errors were those of repeated pilot error. However, accidents cannot be attributed to a single cause, or to a single individual.

In summary, human factors do affect safety performance as demonstrated by the reviewed studies. Besides, human factors are regarded to play a vital part in safety performance and also in accident prevention at the workplace. 


\section{Empirical Studies on Safety Performance}

There are various literatures discussing safety performance as a dependent variable measured by a range of safety outcomes, including accident rates or injuries (Ali, Abdullah, \& Subramaniam, 2009; Fernandez-Muniz et al., 2009; Fernandez-Muniz, Montes-Peon, \& Vazquez-Ordas, 2012; Fernandez-Muniz, Montes-Peon, \& Vazquez-Ordas, 2014; Mearns, Whitaker, \& Flin, 2003; Naveh \& Marcus, 2007; Vredenburgh, 2002).

Fernandez-Muniz et al. (2009) conducted a study to ascertain good practices in safety management and evaluate the influence of these practices on a set of indicators of organizational performance including safety performance, which involving 455 Spanish firms. The questionnaires were sent to safety officer for each firm. The results reveal that safety management has a positive impact on safety performance, competitiveness performance, and economic-financial performance. Later, Fernandez-Muniz et al. (2012) conducted a study to evaluate the safety climate in OHSAS 18001-certified firms and its association with three measures of performance; safety performance, employee satisfaction and firm competitiveness in 131 Spanish firms. The questionnaires were sent to safety officer of each firm. Based on the results, employees' safety behavior has a positive effect on safety performance, employee satisfaction and firm competitiveness. Fernandez-Muniz et al. (2014) later conducted a study to examine the impact of the safety leadership and the proactive risk management in the betterment of occupational safety performance in 188 Spanish firms. A set of self-administered questionnaires were sent to safety manager of each firm. It was determined that proactive risk management and transformational leadership are crucial in encouraging safety performance, in other words, safety behavior.

Vredenburgh (2002) investigated the correlation among management practices and injury rates and involving 62 hospitals in the USA which the respondents were managers. It was determined that management practices reliably predict injury rates. The same kind of study was conducted by Ali et al. (2009) which involved 68 companies in a major industrial zone in Malaysia which revealed the same result as Vredenburgh (2002).

Razuri, Alarcon and Diethelm (2007) concentrated on construction projects in Chile to examine how a safety performance could be enhanced and to identify factors that significantly determine safety performance in the context of construction projects in Chile. Selfadministered questionnaires were administered to the project managers on 60 construction sites. It was determined that 14 factors, including behavior-based safety program, specialized training for workers, orientation and specialized training for management among others, were identified as significant factors. In addition, this study demonstrated safety practices implemented to be correlated with the project injury rate. Abdul-Rashid, Bassioni, and Bawazeer (2007) researched the factors influencing safety performance in large construction companies in Egypt where it involved participants from 79 companies who answered the questionnaires and represented their companies. The finding of this study suggests that among the most significant factors influencing safety performance are safety awareness of company's top management, safety awareness of projects managers and safety inspections.

\section{Organizational Safety Practices}

Bottani et al. (2009) observes that human factors constitute the highest contributors to workplace safety. Human factors can be either viewed from the employees or employers' perspectives. Among the common employer-related factor examining an employee's performance is organizational safety practices (Ali et al., 2009; Vredenburgh, 2002).

Organizational safety practices are the prudent methods or techniques in achieving the organizational goals by optimum use of resources (Dorji \& Hadikusumo, 2006). In this study, organizational safety practices comprises of employee participation, training, management commitment, and communication and feedback. These practices are relevant to improve the capabilities of employees in encountering and preventing accidents and injuries in the workplace as well as to improve safety performance (Ali et al., 2009; Vredenburgh, 2002). The following section empirically examines these practices.

\section{Employee Participation}

Employee participation is defined as the participation of employees or employees' involvement. Employee participation consists of collective involvement of the employees in the upward communication flow and in the process of decision-making process in an organization (Khan, 2010). Management recognizes employee participation based on the knowledge and experience of organizations working to improve the level of safety due to the commitment given by all the employees who are directly involved are getting better with the involvement of all parties affected by such decisions (Ariss, 2003; Burns, 2002). Thus, employee can influence management decision made at various hierarchical levels in an organization (Hem, 1980).

Previous empirical studies have revealed the existence of a link between employee participation and safety issues. Studies by Griffiths (1985) and Shannon, Mayr \& Haines (1997) demonstrate that organization with managerial styles and incentives, which practices management appreciation of employee participation via training for new employees, daily communication, safety activities, and frequent training for existing employees among workers and supervisors concerning health and safety, has lesser accident rates. The argument concerning the benefits of employee participation in workplace safety is further extended in Gevers' (1983) study. The employees serve a crucial role in accidents prevention and the employer may collaborate with their employees to propose solutions to safety problems. More importantly, Gevers highlights the importance of cooperation between the employer and employees in improving the working condition in the company.

Clarke (1982) conducted a study to examine workers' participation in health and safety in Canada. The study posits that there is a significant correlation among employee participation and prevention of industrial accidents. In a related study, Walters (1998) conducted a study to investigate the correlation between employee participation in health and safety activities among employees in agricultural sector in the UK. The results indicate that the achievement of employee participation in safety and health is the outcome of the experience and commitment of employees to organization. The study also implies that employees with considerable years of working experience in this sector are able to acutely identify hazards and infringements of safety standards. 
Rooney (1992) found a significant correlation among employee participation in decision making and in establishing a safer workplace which recognizes the significance of employee involvement in the actual designing and implementation of organizational plans and policies. In another study, Shannon et al. (1996) examined workplace organizational correlates of lost-time accident rates in manufacturing. Questionnaires were sent by mail to companies under six types of industries, including metal articles, plastic articles, grain products, textile manufacturing, printing and automobile manufacturing for data collection. They determined that increasing participation of employees in safety issues resulted in a low rate of accidents and occupational injuries at the workplace.

\section{Training}

Training on safety and health is one of the aspects highlighted in the domain of safety and health of workers (Dessler, 2004; Goetsch, 2011; Roughton \& Mercurio, 2002; Schneid, 2000; Stewart, 2002). Training is important in raising the awareness of employees on safety and health issues. When the employees are conscious, it is easier for them to solve their safety problems and be more careful when they are on duty. Training is very essential for employees to stay focused and prepared in doing their job.

Lin and Mills (2001) affirmed that clear policy statements and safety training are able to reduce accident and injury rates. In the same disposition, a study by Farooqui, Arif and Rafeeqi (2008) on safety performance in construction industry of Pakistan, which involved data from 27 sites, shows that training is an important factor affecting safety performance. They also suggest that construction workers must be well-trained with job-related safety and health training.

Vassie and Lucas (2001) assess health and safety management in manufacturing companies in the UK. They found that a successful training leads employees to feel a sense of belonging, consequently makes them more responsible and alert to their workplace safety. Further, Zacharatos, Barling and Iverson (2005) carried out a study to evaluate the link concerning occupational safety and highperformance work systems which involved 138 safety directors in human resource company. They found that employees who participate in safety training programs encounter fewer work-related injuries than those who do not. Moreover, they determine a significant correlation among safety training and high performance whereby a good training for workers could improve the level of occupational safety, leading to high performance.

Chen and Jin (2011) carried out a study to determine the impact of safety management on safety performance in the USA construction industry which is based on a case study of an on-site safety management program initiated by a general contractor. This study supports the necessity of training as the future accidents preventive measure for new workers. Geldart, Smith, Shannon and Lohfeld (2010) conducted a study to investigate organizational practices and workplace health and safety for manufacturing firms in the province of Ontario, Canada involving 312 managers for data collection. The study discovered indication corroborating the relationship concerning safety training and lower injury rates.

\section{Management Commitment}

The commitment from the top level in an organization towards the implementation of safety practices within the organization is essential (Ismail, 2006; Stranks, 2006; Zakaria, 2003). The management must be committed in setting goals towards improving operations to achieve organizational goals in implementing safety culture (Brook, 1997; Collinson, 1999; Cooper, 1998; Roughton \& Mercurio, 2002). Goetsch (2011) contends that the management commitment is the key in the development and implementation of a safety program. It becomes important especially when there is an attempt to prevent workplace accidents. Culture requires a change of adherence to commitments (Bain, 2005; Marlow \& Weyman, 2004). To ensure the successful development of organizational culture, it requires commitment especially from the head of an organization (Ruchlin, Dubbs, Callahan, \& Fosina, 2004). Cooper (1998) demonstrates that management commitment is vital in the safety change process and safety auditing. The same proposition is held by Reason (1990), postulating that management commitment is the driving force behind organizational safety.

Previous empirical examinations have indicated the existence of a link between management commitment and safety issues. For instance, Geldart et al. (2010) conducted a study to determine organizational practices and workplace health and safety in Canadian manufacturing companies. The data were collected from 312 manufacturing firms using mailed questionnaires. The results from the study show a significant influence of management commitment on injury occurrence at the workplace. Miozza and Wyld (2002) examined the perspective of American safety professionals on behavior and incentive-based protection programs. They determine that the success of behavior-based safety in reducing injuries is not without the commitment and involvement of each level of management.

\section{Communication and Feedback}

Communication and feedback are defined as the important factors in the delivery of information and data on the organizations' safety level. Communication and feedback are the medium for managers to determine the extent of risk caused by accidents at workplace (Kletz, 1993). Additionally, communication and feedback influence the employees' performance in organizations (Bentley \& Haslam, 2001). Tracking errors at work and correcting deviations as soon as possible by management are both aided by efficient communication and feedback (Pandey \& Garnett, 2006).

Previous research works have revealed empirically the importance of communication and feedback in enhancing safety performance (Ali et al., 2009; Bentley \& Haslam, 2001; Fernandez-Muniz et al., 2009). Bentley and Haslam (2001) investigated the similarities of safety practices utilized by managers to determine high and low accident rates in postal delivery offices in the UK. The data collected from interviews with 20 delivery office managers reveal that safety communication is related to low accident rates. Furthermore, Ali et al. (2009) discovers that communication and feedback are significantly related to the rates of injury in the industrial sector in Malaysia which suggesting that the regular feedback on safety does reduce injury rates. Likewise, Fernandez-Muniz et al. (2009) found that safety management system, including communication, has a positive effect on safety performance.

Vecchio-Sadus (2007) conducted a study to enhance safety culture through effective communication in Australia. This study used case study to elucidate how an organization responds to a decrease in injury and accident. The study showed that decrease in injury performance with a variety of safety communication techniques whereby communication is an important factor in influencing 
organization's safety level. In a similar study, Dingsdag, Biggs, Sheahan and Cipolla (2006) conducted a study to determine the relationship among safety competency framework and safety culture in Australian construction industry. 49 interviews with managers reveal that communication has a positive impact on safety culture. Similarly, Sawacha, Naoum, and Fong (1999) conducted a study to investigate the factors affecting safety performance in the UK construction sites. The questionnaires sent to 120 site managers yielded insights that safety communication is associated with site safety.

\subsection{PROPOSED FRAMEWORK}

The framework of this study has proposed organizational safety practices as independent variable and safety performance as dependent variable. Safety performance is generally measured by safety outcomes through accident or injury rate (Mearns et al., 2003; Niskanen, 1994; Vredenburgh, 2002) as shown in Figure 1 below and also through safety behaviour (Cooper \& Philips, 2004; Neal, Griffin, \& Hart, 2000; O’Dea \& Flin, 2001). Many scholars (e.g. Chang \& Yeh, 2005; Enshassi et al., 2008; Griffin \& Neal, 2000) have emphasized the essentiality of increasing safety to decrease occupational accidents.

Prior studies have showed that safety performance is influenced by organizational safety practices (Ali et al., 2009; Dorji \& Hadikusumo, 2006; Fernandez-Muniz et al., 2009; Geldart et al., 2010: Mearns et al., 2003; Razuri et al., 2007; Vredenburgh, 2002). Additionally, organizational safety practices have the capacity to address threats and circumstances that stimulate the occurrence of human errors by improving safety standards in the organization (Barling, 2001). Therefore, this study adopts organizational safety practices as the independent variable for the reasons above.

Organizational Safety Practices

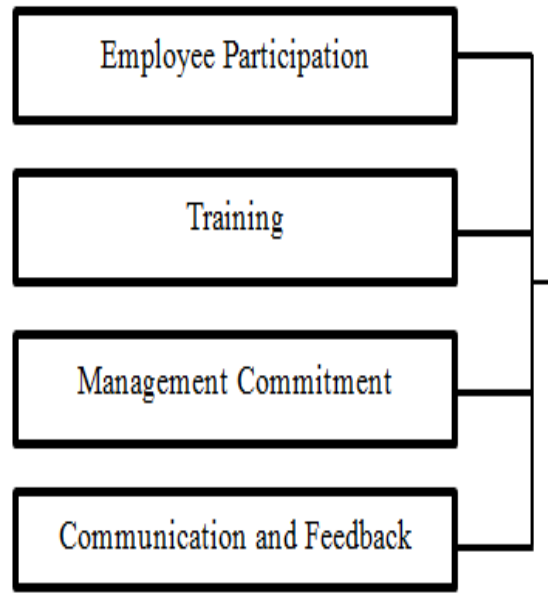

Safety Performance

- Safety Compliance

- SafetyParticipation

- Safety Outcomes

- Employee Satisfaction

Figure 1 Theoretical framework

\subsection{CONCLUSION}

The main objective of this paper was to review the related empirical literatures and highlight the need to investigate safety performance among manufacturing SMEs in Malaysia.

Recent reviews on safety performance found that safety performance refers to the accident or injury rates in an organization (Fernandez-Muniz et al., 2014). Safety performance could be expected to have an impact in the prevention of accidents and injuries, as well as in measuring workplace safety.

Previous studies on organizational safety practices and safety performance indicated that these practices can help improve safety performance. Moreover, previous studies on organizational safety practices have indicated that the role of employee participation, training, management commitment and communication and feedback in improving safety performance. Thus, in the present study organizational safety practices will be examine as independent variable towards safety performance.

\section{References}

80 peratus kemalangan industri babitkan IKS. (2010, 16 December). Berita Harian Online. Retrieved from http://bharian.com.my

Abdul-Rashid, I., Bassioni, H., \& Bawazeer, F. (2007). Factors Affecting Safety Performance In Large Construction Contractors In Egypt. Paper presented at the Proceedings 23rd Annual ARCOM Conference, 3-5 September 2007, Association of Researchers in Construction Management, Belfast, UK, 661-670.

Ali, H., Abdullah, N. A. C., \& Subramaniam, C. (2009). Management Practice In Safety Culture And Its Influence On Workplace Injury: An Industrial Study in Malaysia. Disaster Prevention and Management, 18(5), 470-477. 
Ariss, S. S. (2003). Employee Involvement To Improve Safety In The Workplace: An Ethical Imperative. Mid-American Journal of Business. 18(2), 9-16.

Bain, B. (2005). Creating a safety culture at Suncor Energy Inc. Paper presented at 55th Canadian Chemical Engineering Conference. October 16-19. Toronto: Suncor Energy.

Barling, J. (2001). Management Practices Affect Occupational Safety. Ontario, Canada: School of Business, Queen's University.

Bellamy, L. J., Geyer, T. A. W., \& Wilkinson, J. (2008). Development Of A Functional Model Which Integrates Human Factors, Safety Management Systems And Wider Organisational Issues. Safety Science, 46, 461-492

Bentley, T. A., \& Haslam, R. A. (2001). A Comparison Of Safety Practices Used By Managers Of High And Low Accident Rate Postal Delivery Offices. Safety Science, 37, 19-37.

Booth, R. T., \& Lee, T. R. (1995). The Role Of Human Factors And Safety Culture In Safety Management. Journal of Engineering Manufacture, 209, 393-400.

Bottani, E., Monica, L., \& Vignali, G. (2009). Safety Management Systems: Performance Differences Between Adopters And Non-Adopters. Safety Science, 47, 155162.

Brook, I. (1997). Leadership Of Cultural Changes Process. Journal of Health Manpower Management, 23(4), 113-119.

Burns, T. E. (2002). Serious Incident Prevention: How To Sustain Accident-Free Operation In Your Plant Or Company. (2nd ed.). Woburn, MA: Elsevier Science.

Chang, H. -L., \& Yeh, C. -C. (2005). Factors Affecting The Safety Performance Of Bus Companies - The Experience Of Taiwan Bus Deregulation. Safety Science, $43,323-344$

Chen, Q., \& Jin, R. (2011). An Effective Approach To Enhancing Jobsite Safety Management And Performance: Case Study. Paper presented at the 47th Associated Schools of Construction Annual International Conference Proceedings, USA.

Clarke, R. D. (1982). Worker Participation In Health And Safety in Canada. International Labour Review, 121(2), 199-206.

Collinson, D. L. (1999). 'Surviving the Rigs': Safety and Surveillance on North Sea Oil Installations. Organization Studies, 20(4), 579-600.

Cooper, M. D. (1998). Improving Safety Culture: A Practical Guide. Chichester: John Wiley \& Sons.

Cooper, M. D., \& Phillips, R. A. (2004). Exploratory Analysis Of The Safety Climate And Safety Behavior Relationship. Journal of Safety Research, 35, 497-512.

Department of Statistics Malaysia (2014). Economic Census 2011: Profile of Small and Medium Enterprise. Retrieved from http://www.statistics.gov.my/portal/index.php?option=com_content\&view=article \&id=1721\&IteIte=149\&lang=en \#10.

Dessler, G. (2004). A Framework for Human Resource Management. 3rd. ed. New Jersey: Prentice Hall.

Dingsdag, D. P., Biggs, H. C., Sheahan, V. L., \& Cipolla, D. J. (2006). A Construction Safety Competency Framework: Improving OH\&S Performance By Creating And Maintaining A Safety Culture. In: Cooperative Research Centre for Construction Innovation, Brisbane.

Dorji, K., \& Hadikusumo, B. H. W. (2006). Safety Management Practices In The Bhutanese Construction Industry. Journal of Construction in Developing Countries, 11(2), 53-75

Enshassi, A., Choudhry, R. M., Mayer, P. E., \& Shoman, Y. (2008). Safety Performance Of Subcontractors In The Palestinian Construction Industry. Journal of Construction in Developing Countries, 13(1), 51-62.

Fahlbruch, B. (2009). Integrating Human Factors in Safety and Reliability Approaches. Paper presented at Proceedings of the 4th European-American Workshop on Reliability of NDE, Berlin, June 24-26, 2009.

Fahlbruch, B., \& Wilpert, B. (1999). System Safety - An Emerging Field For I/O Psychology. International Review of Industrial and Organizational Psychology, 14, $55-93$.

Farooqui, R. U., Arif, F., \& Rafeeqi, S. F. A. (2008). Safety Performance In Construction Industry of Pakistan. Paper presented at Proceedings of the 1st International Conference on Construction in Developing Countries. Karachi, Pakistan, 4-5 August.

Fernandez-Muniz, B., Montes-Peon, J. M., \& Vazques-Ordas, C. J. (2007). Safety Management System: Development And Validation Of A Multidimensional Scale. Journal of Loss Prevention in the Process Industries, 20, 52-68.

Fernandez-Muniz, B., Montes-Peon, J. M., \& Vazquez-Ordas, C. J. (2012). Safety Climate In OHSAS 18001-Certified Organisations: Antecedents And Consequences Of Safety Behaviour. Accident Analysis and Prevention, 45, 745-758.

Fernandez-Muniz, B., Montes-Peon, J. M., \& Vazquez-Ordas, C. J. (2014). Safety Leadership, Risk Management And Safety Performance in Spanish firms. Safety Science, 70, 295-307.

Fernandez-Muniz, B., Montes-Peon, J. M., \& Vazquez-Ordas, C. J., (2009). Relation Between Occupational Safety Management And Firm Performance. Safety Science, 47, 980-991.

Geldart, S., Smith, C. A., Shannon, H. S., \& Lohfeld, L. (2010). Organizational Practices And Workplace Health And Safety: A Cross-Sectional Study In Manufacturing Companies. Safety Science, 48, 562-569.

Gevers, J. K. M. (1983). Worker Participation In Health And Safety In The EEC: The Role Of Representative Institutions. International Labour Review, 122(4), 411428

Goetsch, D. L. (2011). Occupational Safety And Health For Technologist, Engineers, And Managers (7th ed.). New Jersey: Pearson Education International.

Gordon, F., \& Risley, D. (1999). The Costs To Britain Of Workplace Accidents And Work- Related Ill Health in 1995/1996 (2nd ed.). HSE Books, London.

Gordon, R., Flin, R., \& Mearns, K. (2005). Designing And Evaluating A Human Factors Investigation Tool (HFIT) For Accident Analysis. Safety Science, 43, 147171.

Griffin, M. A., \& Neal, A. (2000). Perceptions Of Safety At Work: A Framework For Linking Safety Climate To Safety Performance, Knowledge, And Motivation. Journal of Occupational Health Psychology, 5(3), 347-358.

Griffiths, D. K. (1985). Safety Attitudes Of Management. Ergonomics, 28(1), 61-67.

Heinrich, H. W., Peterson, D., \& Roos, N. (1980). Industrial Accident Prevention. New York: McGraw-Hill.

Hem, C. J. (1980). Worker Participation: Success And Problems. New York: Praeger Publishers.

Hollnagel, E. (1993). Human Reliability Analysis: Context And Control. London: Academic Press.

Hughes, G., \& Kornowa-Weichel, M. (2004). Whose Fault Is It Anyway? A Practical Illustration Of Human Factors In Process Safety. Journal of Hazardous Materials, 115, 127-132.

Ismail Bahari. (2006). Pengurusan Keselamatan dan Kesihatan Pekerjaan. (2nd ed.). Kuala Lumpur: McGraw-Hill.

Jiang, L., Yu, G., Li, Y., \& Li, F. (2010). Perceived Colleagues' Safety Knowledge/Behavior And Safety Performance: Safety Climate As A Moderator In A Multilevel Study. Accident Analysis and Prevention, 42, 1468-1476.

JKKP giat kurangkan kemalangan tempat kerja. (2015, 7 October). Sinar Harian, p. 42.

Khan, M. A. (2010). Effect Of Human Resource Management Practices On Organizational Performance - An Empirical Study Of Oil And Gas Industry In Pakistan. European Journal of Economics, Finance and Administrative Sciences, 24, 157-175.

Kletz, T. A. (1993). Lessons From Disaster: How Organisations Have No Memory And Accidents Recur. United Kingdom: Institution of Chemical Engineers.

Kuhlmann, A. (2003). Does Safety Science Fulfill The Requirements Of Modern Technical Systems? Human Factors and Ergonomics in Manufacturing, 13(3), 223230.

Leman, A. M. A. R. Omar, \& M. Z. M. Yusof. (2010). Monitoring of Welding Work Environment in Small and Medium Industries (SMIs). IJRRAS, 5, 18-26.

Lin, J., \& Mills, A. (2001). Measuring The Occupational Health And Safety Performance Of Construction Companies in Australia. Facilities, 19(3/4), 131-138.

Marlow, P., \& Weyman, A. (2004). What works in HSE? Exploring The Contextual Knowledge Of Operational Staff. Research Report HSL/2004/11. Sheffield: Health and Safety Laboratory.

Mearns, K., Whitaker, S. M., \& Flin, R. (2003). Safety Climate, Safety Management Practice And Safety Performance In Offshore Environments. Safety Science, 41, $641-680$.

Miozza, M. L., \& Wyld, D. C. (2002). The Carrot Or The Soft Stick? The Perspective Of American Safety Professionals On Behaviour And Incentive-Based Protection Programmes. Management Research News, 25(11), 23-41.

Naveh, E., \& Marcus, A. (2007). Financial Performance, ISO 9000 Standard And Safe Driving Practices Effects On Accident Rate In The U.S. Motor Carrier Industry. Accident Analysis and Prevention, 39, 731-742.

Neal, A., Griffin, M. A., \& Hart, P. M. (2000). The Impact Of Organizational Climate On Safety Climate And Individual Behavior. Safety Science, 34, 99-109.

Niskanen, T. (1994). Safety Climate In The Road Administration. Safety Science, 17, 237-255.

O’Dea, A., \& Flin, R. (2001). Site Managers And Safety Leadership In The Offshore Oil And Gas Industry. Safety Science, 37, 39-57.

Pandey, S. K., \& Garnett, J. L. (2006). Exploring Public Sector Communication Performance: Testing A Model And Drawing Implications. Public Administration Review, 66(1), 37-51.

Razuri, C., Alarcon, L. F., \& Diethelm, S. (2007). Evaluating The Effectiveness Of Safety Management Practices And Strategies In Construction Projects. Paper presented at Proceedings of the 15th Annual Conference of the International Group for Lean Construction IGLC-15, 18-20 July 2007, Michigan, USA.

Reason, J. (1990). Human error. New York: Cambridge University Press.

Rooney, P. M. (1992). Employee Ownership And Worker Participation: Effects On Health And Safety. Economic Letters, 39, 323-328.

Roughton, J. E., \& Mercurio, J. J. (2002). Developing an Effective Safety Culture: A Leadership Approach. Woburn: Butterworth-Heinemann.

Ruchlin, H. S., Dubbs, N. L., Callahan, M. A., \& Fosina, M. J. (2004). The Role Of Leadership In Instilling A Culture Of Safety: Lessons From The Literature. Journal of Healthcare Management, 49(1), 47-59. 
Ryerson, M., \& Whitlock, C. (2005). Use Of Human Factors Analysis For Wildland Fire Accident Investigations. Paper presented at the Proceedings of the Eighth International Wildland Fire Safety Summit, Missoula, USA (April 26-28, 2005).

Saleh, A. S., \& Ndubisi, N. O. (2006). An evaluation of SME development in Malaysia. International Review of Business Research Papers, $2(1), 1-14$.

Salmon, P. M., \& Lenne, M. G. (2009). Systems-Based Human Factors Analysis Of Road Traffic Accidents: Barriers And Solutions. Paper Presented at the Australasian Road Safety Research, Policing and Education Conference, Sydney, Australia.

Sawacha, E., Naoum, S., \& Fong, D. (1999). Factors Affecting Safety Performance On Construction Sites. International Journal of Project Management, 17(5), 309. 315 .

Schneid, T. D. (2000). Modern Safety and Resource Control Management. New York: John Wiley \& Sons.

Shang, K. -C, Yang, C. -S, Lu, C. -S. (2011). The Effect Of Safety Management On Perceived Safety Performance In Container Stevedoring Operations. International Journal Shipping and Transport Logistics, 3(3), 323-341.

Shannon, H. S., Walters, V., Lewchuk, W., Richardson, J., Moran, L. A., Haines, T., \& Verma, D. (1996). Workplace Organizational Correlates Of Lost-Time Accident Rates In Manufacturing. American Journal of Industrial Medicine, 29, 258-268.

Shannon, H., Mayr, J., \& Haines, T. (1997). Overview Of The Relationship Between Organizational And Workplace Factors And Injury Rates. Safety Science, 26, 201-217.

Small Medium Enterprise Corporation Malaysia (SME Corp.) (2014). SME Annual Report 2014/2015. Retrieved from SME Corporation: http://www.smecorp.gov.my

Social Security Organization. Annual Report (2010-2014)

Stewart, J. M. (2002). Managing for World Class Safety. New York: John Wiley \& Sons.

Stranks, J. (2006). The A-Z Health and Safety. London: Thorogood Publishing Ltd.

Surienty, L., Hong, K. T., \& Hung, D. K. M. (2011). Occupational safety and health in SMEs in Malaysia: A Preliminary Investigation. Journal of Global Entrepreneurship, 1(1), 65-75.

Tam, C. M., Zeng, S. X. \& Deng, Z. M. (2004). Identifying Elements Of Poor Construction Safety Management in China. Safety Science, $42,569-586$.

Three Sectors Major Contributors To Accidents At Workplace. (2014, 30 September). Bernama. Retrieved from www.mtuc.org.my

UK HSE (2003). Factoring The Human Into Safety: Translating Research Into Practice. Research report, Prepared by the University of Aberdeen for the HSE.Manufacturing Sector. Journal of Safety Research, 32, 479-490.

Vecchio-Sadus, A. M. (2007). Enhancing Safety Culture Through Effective Communication. Safety Science Monitor, 11(3), 1-9.

Vinodkumar, M. N., \& Bhasi, M. (2010). Safety Management Practices And Safety Behaviour: Assessing The Mediating Role Of Safety Knowledge And Motivation. Accident Analysis and Prevention, 42, 2082-2093.

Vredenburgh, A. G. (2002). Organizational Safety: Which Management Practices Are Most Effective In Reducing Employee Injury Rates? Journal of Safety Research, $33,259-276$.

Walters, D. (1998). Employee Representation And Health And Safety - A Strategy For Improving Health And Safety Performance In Small Enterprises? Employee Relations, 20(2), 180-195.

Wiegmann, D. A., \& Shappell, S. A. (2001). Human Error Analysis Of Commercial Aviation Accidents: Application Of The Human Factors Analysis And Classification System (HFACS). Aviation Space and Environmental Medicine, 72, 1006-1016.

Wolfram, J. (1993). Safety And Risk: Models And Reality. Journal of Process Mechanical Engineering, 207(1), 3-11.

Zacharatos, A., Barling, J., \& Iverson, R. D. (2005). High-Performance Work Systems And Occupational Safety. Journal of Applied Psychology, 90(1), 77-93.

Zakaria Ismail. (2003). Relationship Between Top Management Involvement And Employees' Compliance To OSH Rules And Regulations: An Empirical Study In The Manufacturing And Construction Firms In Malaysia. Paper Presented at Proceedings of the 19th Annual Conference of Asia Pacific Occupational Safety and Health Organisation (OPOSHO 19). 2-3 September, Kuala Lumpur. 